\title{
Strengthening the Character of Students Based on Local Cultural Wisdom in "Petatah Petitih Sunan Gunung Jati"
}

\author{
${ }^{1}$ Linda Eka Pradita, ${ }^{2}$ Sumarlam, ${ }^{3}$ Kundharu Saddono, ${ }^{4}$ Muhammad Rohmadi ${ }^{4}$ \\ linda.ekapradita85@gmail.com
}

Sebelas Maret University

\begin{abstract}
Character education has a higher meaning because it is not only related to the problem right wrong but how to instill habits about various good behaviors in life, so that children have high awareness and understanding. This study aims: (1) the meaning contained in local wisdom and (2) Application of local wisdom-based character education in elementary school education. Data collection techniques were carried out by (1) interviews, (2) observation, (3) documentation. Research results: (1) the meaning contained in local wisdom. The details of Sunan Gunung Jati generally contain broad and complex meanings, so that they can be useful, not only for their children and offspring, but also for the wider community. Basically there are six meanings contained in the recitations of Sunan Gunung Jati, namely advice on good deeds, consistency in carrying out the teachings of Islam, subtle and hard reprimands, obeying agreed rules, upholding the values of Islamic teachings, and social sanctions. (2) the application of character education based on local wisdom based on the character values contained in one of the local cultures of Cirebon City. The local cultural wisdom of the Cirebon community comes from Sunan Gunung Jati, especially the petitih Sunana Gunung Jati, which contains character values, namely devotion and belief, discipline, wisdom and policy, politeness and manners and social life.
\end{abstract}

Keyword: Character Education and Local Cultural Wisdom

\section{Introduction}

Indonesia is an archipelago that has diverse cultural wealth. As an archipelago, the lives of its people also become very multicultural. Multicultural cultural awareness, of course, must have been instilled in individuals from an early age to avoid reprehensible attitudes. The goal is that social conflicts that often occur in the midst of society can be minimized and overcome. If viewed contextually in diversity contained local values or local wisdom that can be used to maintain social harmony.

Efforts to prepare better future generations through education should be carried out early. When viewed from the developmental psychology, elementary school age children are a defining period for the development of children at a later stage of development. During this time the child is in a sensitive situation to receive external stimuli. If at this time the child receives stimuli that are in accordance with the stages of child development will develop optimally. This age is the most appropriate time to habituate in the formation of a person's character.

Local wisdom is the capital of noble character formation. A noble character is the character of a nation that always acts with full awareness. Character is the values of human behavior that relate to God Almighty, self, fellow human beings, environment and nationality manifested in thoughts, attitudes, feelings, words and deeds based on the norms of religion, law, manners, culture and customs. Thomas Lickona[1] states that the notion of character education is a deliberate effort to help someone so that they can understand, pay attention to, and carry out ethical values. Character education is expected to form good, honest and noble behavior. The implementation of Indonesian national character education does not stand alone but integrates with existing lessons by incorporating national character and cultural values based on local wisdom. According to Tilaar[2] local wisdom has a pedagogical value because it aims to regulate behavior that is beneficial to the common interests of the community.

Local wisdom can be derived from the culture of society in a particular locality. In a historical perspective, local wisdom can shape a local history. The tradition of local wisdom of the Cirebon community generally comes from traditions taught by Sunan Gunung Jati, especially on the teachings of Sunan Gunung jati which contain a broad and complex meaning. The elements of the teachings of Sunan Gunung Jati are the rules in devotion and belief, discipline, wisdom and policy, politeness and manners, and social life. One of the 
popular breeders in the community is "ingsun titipna tajug lan fakir miskin". This means that the word Kanjeng Sunan Gunung Jati, I entrust the mosque or mosque and the poor.

These values are needed in shaping the character of a child. Although these values are extracted from local cultural potential, these values are universal, so they can be used as general values and can be used by anyone, anywhere, anytime, especially in early childhood education. So educational institutions can apply local wisdom in their area to educate students' character.

The meaning of local wisdom in the world of education is still very lacking. There is local content in the structure of the educational curriculum, but the meaning is very formal because the content is less explored by local wisdom. Local content is only limited to the regional language taught to students. The challenges of education are very complex if linked to global progress in the field of science and technology, local values begin to fade and be abandoned. Therefore, exploration of the noble wealth of the nation's culture is very necessary. Local wisdom actually contains many examples and wisdom of life. The importance of local wisdom in education is part of an effort to improve a nation's national security.

The values of local wisdom are expected to be able to stay alive and support the community. The personality of a society is determined by the strength and ability of the local genius in dealing with external forces. If the local genius is lost or destroyed, then the nation's personality also fades. In order for the existence of culture to remain strong, the nation's future generation needs to instill a sense of love for local culture, especially in the region. One way that can be taken at school. The purpose of this study is to find out and analyze the meaning contained in local wisdom and the application of character education based on local cultural wisdom in elementary school students.

\section{Related Works/Literature Review}

\section{Understanding of Local Cultural Wisdom}

Etymologically, local wisdom comes from wisdom and local (local) words. Wisdom means wisdom and local means local. Local wisdom or local wisdom, namely ideas, values, local views that are wise, full of wisdom, good value embedded and followed by members of the community. Gobyah[3] states that local wisdom is defined as truth that has been internalized or fixed in an area. Substantially, local wisdom is the values that apply in a society. Wisdom is expressed in the form of wise words (philosophy) in the form of advice, proverb, pantun, poetry, folklore (oral stories) and so on.

Local wisdom is formed as the superiority of local culture and geographical conditions in a broad sense. Local wisdom is a cultural product of the past that is constantly used as a guide to life. Although it is of local value, the values contained therein are considered to be very universal and can be reflected in everyday life. As for local wisdom that reflects cultural values include welfare, hard work, discipline, education, health, mutual cooperation, gender management, cultural preservation and creativity, caring for the environment, peace, politeness, honesty, social solidarity, harmony and conflict resolution, commitment, positive thoughts, and gratitude Sibarani[4].

Local wisdom is a culture that is owned by certain communities and in certain places that are considered able to survive in the face of globalization, because local wisdom contains values that can be used as a means of developing national character Yunus[5]. Local wisdom according to Rahyono (2009: 7) local wisdom is human intelligence possessed by certain ethnic groups obtained through community experience. That is, local wisdom is the result of certain communities through their experience and not necessarily experienced by other communities. These values will be very strongly attached to certain communities and that value has been through a long time journey, throughout the existence of the community.

Local knowledge (local indigenous knowledge), local intelligence (local genius), local skills (local skills), local resources, as well as cultural norms and values are local wisdoms that can be utilized for overcome the problems faced by society today and prepare the younger generation in the future Sudikan[6]. On that basis, local wisdom can be defined as local cultural values that can be used to regulate the order of community life wisely and wisely.

Every nation or ethnic group certainly has a different source in forming the character of the next generation. In the formation of the character of the Indonesian nation, local wisdom which is a legacy of noble cultural values becomes an important source that must be owned by the next generation. Character education that is applied systematically and sustainably to children will become emotionally intelligent. Emotional intelligence is an important provision in preparing children to meet the future and be ready to face the challenges of life, including the challenge of succeeding academically. Thus, an understanding of local wisdom as the noble cultural values of the nation can be used as a source of character building for the younger generation. 


\section{Understanding of Character Education}

Character is the values of human behavior that relate to God Almighty, self, fellow human beings, environment and nationality which are manifested in thoughts, attitudes, feelings, words, and actions based on religious, legal, manners, cultural norms and customs. According to Lickona, the character is related to the concept of morality (moral knonwing), moral attitude (moral felling), and moral behavior (moral behavior). Based on these three components, it can be stated that good character is supported by knowledge of goodness, desire to do good, and do good deeds.

Furthermore, it should be stated about the definition of Character Education according to the Expert as follows:

a. Character education according to Lickona: states that character education is a deliberate effort to help someone so that they can understand, pay attention to, and carry out core ethical values.

b. Character education according to Suyanto (2009: 19) defines "character as a way of thinking and behaving that characterizes each individual to live and work together, both within the family, community, nation and state".

c. Character education according to Hidayatullah[7] states character is the quality or mental or moral strength, character or individual character which is a special personality that distinguishes from other individuals.

d. Character education according to Albertus [8] understands character with personality. Personality is considered a characteristic or characteristic, style, characteristic of a person that comes from the formations received from the environment, such as family in childhood and innate from birth.

Based on the description above, it can be concluded that character education has a higher meaning than moral education, because not only teaches what is right and what is wrong, but character education instills habits about things that are good so that children become aware (cognitive domain) about which good and wrong, able to feel (affective domain) good value, and willing to do it (psychomotor domain)

\section{Preservation of Local Wisdom Through Education}

Education is a process of providing cultural knowledge and human civilization that is lived and lived by the values and visions that develop and develop in a society Tilaar[9]. Education and culture have something in common with regard to something about values. Elements of culture that are transmitted through education include cultural values, community customs, views on life, and various other concepts of life that exist in society. In addition, various social habits, attitudes and behavior are used in the interaction or association of members in society. Education can only be carried out in a society. There is no educational process without culture and without society. Thus, it seems clear that the role of education is very large in the development and even of a culture.

The value of traditional local wisdom can be appreciated if the value is well recognized. The values of local cultural wisdom if not guarded will experience an extinction process. One of the efforts to maintain it is through the use of local culture in the learning process in schools. Preservation of regional cultural values by seeking, exploring, and studying and actualizing local cultural wisdom is a basic capital that can be used to strengthen national unity Nasir and Hand[10]. Therefore, the solidarity of the socio-cultural solidarity of fellow citizens needs to be re-actualized. In addition, education without a cultural orientation will bring about a generation that lacks spirituality and is far from value.

Relevant research related to local cultural values as a form of local wisdom carried out by several researchers;

First, the study was conducted by Odette C Pannogan entitled Kalinga Values System as Reflected in Their Proverbs. This study discusses the Kalinga Value System which is reflected in the proverb. The purpose of this study is to identify a proverb from the Kalinga tribe to determine its meaning and its social impact on the value system of the Kalinga community. Proverbs need to be preserved so that Kalinga culture can survive. Proverbs in certain tribes can be used to instill culture and educational tools in an effort to maintain their values and traditions. Odette C Pannogan's research has similarities and differences with research conducted by researchers. The research difference lies in the use of anthropolinguistic disciplines as interdisciplinary between linguistics and anthropology namely the study of language, the study of culture, and the study of other aspects of human life. While 
the equation lies in the object that is a proverb or expression which contains the meaning, function, values, norms and local wisdom of an oral tradition. The sustainability of local wisdom will be reflected in the values prevailing in certain community groups. These values become the grip of a group of people who usually will become part of life inseparable through everyday attitudes and behavior.

Second, Research I Nasution, R Sibarani, M Takari, entitled Local Wisdom in the Night with Tradition in Malay Society, Tanjungbalai, North Sumatra, Indonesia. This study discusses the form of local wisdom contained in the traditional Malay community of the Berinai Night in Tanjungbalai. The Berai Night Tradition is part of traditional wedding ceremonies in the Malay community. Local wisdom found in the evening tradition is politeness, gratitude, mutual help, and care for the environment. Local wisdom can be used by the Tanjungbalai Malay community to regulate the social life order. Malays are known as a people who are polite and obedient to the teachings of Islam. Local wisdom found in the tradition of this evening is in accordance with the concept of Malay life which is identical to the religion of Islam and can naturally be used as a way of life. Local wisdom found in the ceremony is a reflection of the life of Malay people in Tanjung Balai. This research has similarities and differences with research conducted by researchers. The research equation lies in the object being studied, namely the wisdom of local traditions as one of the heritage of cultural diversity. The research difference lies in the approach study. The research of I Nasution, R Sibarani, M Takari using an ethnographic approach was used to see the culture of the Tanjung Balai Malay community as a cultural heritage, while researchers used an anthropolinguistic approach to see the interrelationships between culture and language. Aside from being an element of culture, language also functions as the most important means of inheritance, development and dissemination of culture.

Third, Lee Su Kim's research entitled Exploring the Relationship between Language, Culture and Identity. This study discusses the interrelationship of language and culture, and how language and culture have an impact on one's identity. Language is used to preserve culture. Language is not a static process. Language is the main instrument in the expression, transmission and adaptation of culture. Cultural elements have positive values for students if they are included in language teaching. Textbooks and teaching materials must contain local culture and knowledge to instill a sense of pride in one's cultural and national identity. This research has similarities and differences with researchers. The equation is viewed from the aspect of the approach that is anthropologist to observe the cultural elements that become cultural heritage that surrounds a society. Research differences are viewed from the research focus. If this research focuses on the interrelationship of language and culture, and how language and culture have an impact on one's identity. Researchers are focused on revitalizing a traditional phrase that is full of cultural values and can be used as a means to build the character of the younger generation.

\section{Material \& Methodology}

a. Data and Data Sources

The type of data in this study uses qualitative data. Qualitative data in the form of words, schemes and images. According to Sugiyono[11], that data sources are divided into two, namely primary sources and secondary sources. Primary sources are data sources that directly provide data to data collectors, while secondary data are sources that do not directly provide data to data collectors, for example through documents. These data will be analyzed. These data will be analyzed through anthropolinguistic studies to reveal the cultural value contained in the traditional expression of Sunan Gunung Jati. Primary data was obtained through field observations and interviews with informants. Whereas secondary data is obtained from notes or documents relating to the problem under study.

b. Method

This study uses qualitative methods with anthropolinguistic approaches. This type of research is a qualitative descriptive study. Moleong[12] states that qualitative research is a research procedure that produces descriptive data in the form of written and oral words from people and observed behavior. This is in line with Creswell's[13] opinion that qualitative research is a method to explore and understand the meaning that a number of individuals or groups of people are thought to originate from social or humanitarian problems. This research describes and explains the meaning contained in local wisdom. Facts and events in this study are verbal expressions as cultural events that are analyzed 
by anthropolinguistics to reveal the valuable old texts that are still held tightly in the life of the community and the cultural values contained in them.

\section{c. Data Analysis Techniques}

Data analysis techniques in this study using interactive analysis techniques according to Miles and Huberman[14], The steps of data analysis techniques in this study include three components, namely:

The first step is to reduce data. Data reduction phase, (1) researchers conducted the selection process on the basis of the level of relevance and relation to each data group, (2) compiling and classifying data in similar units as categorization activities, 3) making data coding, 4) activities focusing, simplifying and transferring from rough data to field notes through rigorous selection, summary or brief description, and categorizes in one broad pattern.

The second step is the presentation of data. The presentation of the data is directed so that the data from the reduction is organized, arranged in a relationship pattern, so that it is easy to understand. In this step, the researcher compiles relevant data so that information can be concluded. The process can be done by displaying data, making relationships between phenomena to interpret what actually happened and what needs to be followed up to achieve the research objectives.

The third step is drawing conclusions and verification. Draw conclusions based on findings and verify data. The initial conclusions raised were still temporary and would change if found evidence supporting the data collection stage. Verify the data as a process to obtain evidence. If the conclusions raised at the initial stage are supported by strong evidence in a sense consistent with the conditions found when the researcher returns to the field then the conclusions obtained are credible conclusions. At this stage conclusions are drawn about the form of expression in the study of language structure, the content of cultural values and norms as the actualization of local wisdom values as forming characters.

\section{d. Validation}

Test the validity of data in qualitative research using triangulation. Triangulation is defined as a data collection technique that is a combination of various data collection techniques and existing data sources. Trianggulation technique according to Sutopo[15] consists of four types, namely triangulation of sources, methods, researchers, and theory. Source triangulation is also called data triangulation. Source triangulation directs the researcher to collect data using various available sources, such as the results of interviews from resource persons. Triangulation methods are used by collecting similar data but using different methods, such as interview methods, observations and surveys. Triangulation of the theory is used by researchers with a perspective of more than one theory in discussing the problems under study. Researchers must understand the theories used and their relationship with the problems under study so that they can produce accurate conclusions. The theory that is the reference to validate the findings in this study is the theory of anthropolinguistics, local wisdom and character education.

\section{Results and Discussion}

4.1. The meaning contained in the Petatah Petitih Sunan Gunung Jati as local wisdom in the Cirebon community

Local wisdom is an attempt to find truth based on facts or symptoms that apply specifically in a particular community culture. Knowledge that describes local wisdom is the description of attitudes or behavior that reflects the original culture Setiono[16], Through the deepening of local wisdom can be raised scientific knowledge from local wisdoms that develop and are scientific.

Javanese Islamic religious figure, Syarif Hidayatullah, known as Sunan Gunung Jati. He has an important role in passing down noble values with formation. His perspective emphasizes religion and tradition. The tradition of the wisdom of the Cirebon people is very thick with the messages (messages) from the teachings of Sunan Gunung Jati which contain broad and complex meanings. According to Efendi the elements of Sunan Gunung Jati's plots include:

1. Petatah Petitih related to piety and belief

a. Ingsun titipna tajug lan fakir miskin

b. Yen sembahyang kungsi pucuke panah 
c. Yen puasa den kungsi tetaling gundewa

d. Ibadah kang tetep

e. Wedia ing Allah

f. Manah den syukur ing Allah

g. Kudu ngakehaken pertobat

2. Petatah Petitih related to discipline
a. Aja nyindra janji mubarang
b. Pemboraban kang ora patut anulungi
c. Aja janji kejayaan kang ala rauntah

3. Petatah Petitih related to wisdom and policy
a Singkirna sifat kang den wanci
b. Duweha sifat kang wanti
c.Amapesa ing bina batan
d. Angadahna ing perpadu

e.Aja ilok ngamad kang durung yakin

f. Aja ilok gawe bobat

g. Ing panemu aja gawe tingkah

h. Kenana ing hajate wong

i. Aja dahar yen durung ngeli

j. Aja nginum yen durung ngelok

k. Aja turu yen durung katekan arif

1. Yen kaya den luhur

m.Aja ilok ngijek rarohi ing wong

$\mathrm{n}$. Den bisa megeng ing nafsu

o. Angasana diri

p. Tepo saliro den adol

q. Ngoletena rejeki sing halal

r. Aja akeh kang den pamrih

s. Den suka wenan lan suka memberih gelis lipur

t. Gegunem sifat kang pinuji

u. Aja ilok gawe lara ati ing wong

v. Ake lara ati ing wong, namung saking duriat

w.Aja ilok gawe kaniaya ing makhluk

$x$. Aja ngagungaken ing salira

y. Aja ujub ria suma takabur

z. Aja duwe ati ngunek

4. Petatah Petitih related to politeness and manners

a. Den hormat ing wong tua

b. Den hormat ing leluhur

c. Hormaten, emanen, mulyaken ing pusaka

d. Den welas asih ing sapapada

e. Mulyaken ing tetamu

5. Petatah Petitih related to social life
a. Aja anglakoni lunga haji ing Makkah
b. Aja munggah gunung gede utawa manjing ing kawah
c. Aja ngimami atau khotbah ing masjid agung
d. Aja dagangan utawa warungan
e. Aja lunga layaran ing lautan

Petatah Petitih Sunan Gunung Jati are expressions or sayings that contain life teachings in the form of advice, messages, suggestions, criticisms and reprimands, all of which are conveyed and taught in situations of family life. Petatah Petitih Sunan Gunung Jati generally contains broad and complex meaning, so it can be useful not only for children and their offspring, but also for the wider community. There are seven meanings contained in the petitah recitations as follows: 
First, advice about good and wise actions which ultimately descendants of the Sultan and the wider community are expected to be human beings who are wise and wise in dealing with each other as well as patience and trust in worshiping Allah SWT.

Second, the message that implicitly provides direction and guidance for children and their offspring to remain consistent in carrying out the teachings of Islam. While explicitly affirming the provisions expected to be carried out by children and the wider community.

Third, subtly and frankly expressed his stand that is contrary to conscience, people, children and their descendants. This implies the meaning of subtle and harsh rebuke solely aimed at making the norms of life not violated and can be maintained in accordance with the mission brought.

Fourth, it contains recommendations to comply with a regulation that has been agreed upon to continue to be preserved for the sake of future generations, besides having a mission to always reflect and self-reflect.

Fifth, the expectations of his followers so that what has been obtained can be preserved for the sake of the existing values and norms.

Sixth, it contains sanctions in the form of social and moral penalties for those who violate their petatah petitih.

\subsection{Application of Character Education through Learning Based on Local Wisdom}

Local wisdom-based learning to instill character education can be done in 3 ways, namely integrating into subjects, through local content subjects and through self-development.

1. Integrating into Subjects

Integrating into subjects, for example, IPS aims to introduce the values of character education in the subjects so that they are aware of the importance of these values and internalize the values into the daily behavior of students through the learning process, both inside and outside class. Basically learning activities, in addition to making students master the targeted competencies (material), are also designed to make students recognize, realize or care, and internalize values and make them behavior.

In each subject in the Elementary School actually contains materials related to character education. Development of character education values in each subject can be done by integrating character education values into appropriate basic competencies (KD). The number of KD each subject that can be integrated with the values of character education is certainly different, some are absent and some are small. Furthermore, basic competencies that can be integrated into the character education values are developed in the syllabus and learning implementation plan (RPP).

For example based on class IV material competency standards (get to know natural resources, economic activities, and technological progress in the district or city and province) and basic competencies (get to know economic activities related to natural resources and other potential in the area). Character values that can be raised are honest, discipline, hard work, creative, independent, democratic, curiosity, love for the homeland, respect for achievement, friendly or communicative, care for the environment, social care and responsibility.

\section{Integrating into Local Content Subjects}

Local content is curricular activities to develop competencies that are tailored to the characteristics and potential of the region, including the advantages of the area called local wisdom. The material chosen is determined based on the characteristics, potential and advantages of the region, as well as the availability of land, facilities, and educators. The goal of learning local wisdom is the development of an entrepreneurial spirit and the cultivation of cultural values in accordance with the environment. Entrepreneurial values developed include innovation, creative, critical thinking, exploration, communication, independence, and having a work ethic. Cultural values in question include honesty, responsibility, discipline, environmental sensitivity, and cooperation.

The cultivation of entrepreneurial and cultural values is integrated in the learning process that is conditioned so that these values can become attitudes and behaviors in everyday life. In addition, learning based on local wisdom can be done by way of the teacher giving assignments in groups to observe and identify the culture or resources in the neighborhood. Through observation directly into the teacher's environment, there are several goals for students to have after the activity. Expected character values and abilities, namely honesty, discipline, hard work, creative, independent, 
democratic, curiosity, love of the homeland, respect for achievement, friendship or communicative, care for the environment, social care, and responsibility.

\section{Self-development}

Self-development activities include a variety of extracurricular activities based on local culture in accordance with the interests and talents of students, such as extracurricular activities of school wall magazine competitions with content that emphasizes the introduction of local culture, (the excitement through scouts and paskibraka, sports, arts, scientific activities through the Olympics and competitions subjects about social environment and cultural environment Habituation activities (routine activities through flag ceremonies and communal worship) Programmed activities through Ramadhan pesantren, breaking the fast together, performing idul qurban, exemplary through fostering order, discipline, planting noble character, planting a culture of interest read, planting clean culture in the classroom and school environment, planting green culture, nationalism activities through celebrating Indonesia's independence day, commemorating the day of the hero, commemorating the day of national education.

\section{Discussion}

Local wisdom-based learning is learning that places students as student centered learning centers rather than teacher centered. This is in line with Sagala's[17] statement that learning is not just a passive activity of receiving material from the teacher, but rather an active process of exploring old experiences, finding and discovering new experiences and connecting between the two to form meaning. The meaning is created from what students see, hear, feel, and experience. For teachers, teaching is an activity to facilitate students in constructing their own knowledge through their involvement inside.

Associated with learning the values of local wisdom in Primary Schools according to Sutarno[18] there are four kinds of culture-based learning, namely:

a. Learn about culture, namely placing culture as a field of science. Culture is studied in special study programs on culture and for culture. In this case, culture is not integrated with the field of science.

b. Learning with culture occurs when culture is introduced to students as a way or method to learn a particular subject. Learning with culture includes the use of a variety of cultural manifestations. In learning with culture, culture and its manifestation, it becomes a medium of learning in the learning process, becoming the context of examples of concepts or principles in a subject, as well as being the context for the application of principles or procedures in a subject.

c. Learning through culture is a strategy that provides opportunities for students to demonstrate the achievement of understanding or meaning created in a subject through various cultural manifestations.

d. Learning is cultured, is a form of embellishing that culture in students' daily behavior. For example, a child is cultivated to always use the language of the English language on Saturday through the Saturday Culture program.

\section{Conclusion}

Local wisdom actually contains many examples and wisdom of life. The importance of local wisdom in education extensively is part of efforts to increase national security as a nation. Character education not only teaches something that is right and wrong but character education also dwells on habits (habituation) about good things so students learn (cognitive) about what is right and wrong, able to feel (affective) good values and usually do it ( psychomotor).

Character education has identified 18 values derived from religion, Pancasila, culture and national education goals, namely: 1) Religious, 2) Honest, 3) Tolerance, 4) Discipline, 5) Hard Work, 6) Creative, 7) Mandiri , 8) Democratic, 9) Curiosity, 10) Spirit of Nationality, 11) Love of the Fatherland, 12) Appreciate Achievement, 13) Friendly or Communicative, 14) Love of Peace, 15) Love of Reading, 16) Caring for the Environment, 17) Social Care, 18) Responsibility.

Local wisdom-based learning combined with learning in elementary schools is very appropriate. Local wisdom-based learning to instill character education can be done in 3 ways, namely integrating into subjects, through local content subjects and through self-development 


\section{References}

[1] T. Lickona, Pendidikan Karakter: Panduan Lengkap Mendidik Siswa Menjadi Pintar dan Baiktle. Bandung: Nusa Media, 2013.

[2] H. A. . Tilaar, Pedagogik Teoritis untuk Indonesia. Jakarta: Buku Kompas, 2015.

[3] I. K. Gobyah, Pengenalan Kearifan Lokal Indonesia. Jakarta: Rineka Cipta, 2003.

[4] R. Sibarani, Pembentukan Karakter Yang Arif. Medan: Badan Perpustakaan, Arsip, dan Dokumentasi Provinsi Sumatera Utara, 2014.

[5] R. Yunus, Nilai-nilai Kearifan Lokal (Local Genius) Sebagai Penguat Karakter bangsa. Yogyakarta: CV.Budi Utomo, 2014.

[6] Sudikan Setya Yuwana, Kearifan Budaya Lokal. Sidoarjo: Damar Ilmu, 2013.

[7] M. F. Hidayatullah, Guru Sejati: Membangun Insan Berkarakter Kuat dan Cerdasitle. Surakarta: Yuma Perkasa, 2009.

[8] D. K. Albertus, Pendidikan Karakter Utuh dan Menyeluruh. Yogyakarta: Kanisius, 2012.

[9] H. A. . Tilaar, Pendidikan, Kebudayaan, dan Masyarakat Madani. Bandung: Remaja Rosdakarya, 2002.

[10] V. M. Nasir, N. S., \& Hand, "Exploring Sosiocultural Perspectives on race, culture, and Learning. Review of Education Researchtle,” vol. 76, pp. 449-475, 2006.

[11] Sugiyono, Metode Penelitian Kuantitatif, kualitatif, dan R \& D. Bandung: Alfabeta, 2014.

[12] L. J. Moleong, Metodologi Penelitian Kualitatif. Bandung: Remaja Rosda Karya, 2007.

[13] J. W. Creswell, Penelitian Kualitatif \& Desain Riset. Yogyakarta: Pustaka Pelajar, 2013.

[14] M. B. dan A. M. H. Miles, Analisis Data Kualitatif: Buku Sumber tentang Metode-metode Baru. Jakarta: UI Press, 2007.

[15] H. Sutopo, Metodologi Penelitian Kualitatif. Surakarta: UNS Press, 2002.

[16] F. T. bin S. dan L. G. L. Simatupang, "Non-Formal Education as culture transformation agent towards the development of clasical court dance in Yogyakarta, Indonesia," 2014.

[17] S. Sagala, Konsep dan makna Pembelajarano Title. Bandung: CV Alfabeta, 2010.

[18] Sutarno, Pendidikan Multikultural. Jakarta: Direktorat Jendral Pendidikan, 2008. 